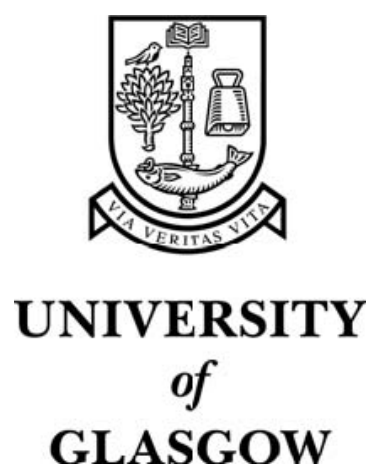

Jones, E. and Danbolt, J. (2004) Joint venture investments and the market value of the firm. Applied Financial Economics 14(18):pp. 1325-1331.

http://eprints.gla.ac.uk/3689/ 


\title{
Joint Venture Investments and the Market Value of the Firm.
}

\author{
Edward Jones* and Jo Danbolt** \\ * School of Management, Heriot-Watt University, Edinburgh. \\ ** Department of Accounting and Finance, University of Glasgow.
}

\begin{abstract}
This paper examines the impact of Joint Venture announcements on the market value of UK listed companies. Based on a sample of 158 announcements of either joint venture formation or joint venture activities, we observe significant positive marketadjusted abnormal returns of $0.5 \%$ on the announcement date. Cross-sectional analysis reveals that abnormal returns are significantly lower when undertaken by large companies, or where the project is located in Asia. On the other hand, marketadjusted returns are found to be significantly higher when the project is large compared to the size of the company undertaking the investment, and where the project is either domestic or located within the European Union.
\end{abstract}

\section{Keywords: Capital Investment, Joint Ventures, Event Study}

JEL: $\quad$ G14, G30

Correspondence: Edward Jones, School of Management, Heriot-Watt University, Riccarton, Edinburgh, EH14 4AS. Telephone +44 (0)131 451 3905, Fax +44 (0)131 451 3008, E-mail: E.A.E.Jones@hw.ac.uk. 


\section{Joint Venture Investments and the Market Value of the Firm.}

\section{Introduction}

In this paper we examine the stock market reaction to the announcement of joint venture activities. McConnell and Nantell (1985) identify joint ventures as the most appropriate test of the existence of an inter-corporate synergy effect. Empirical evidence on the market valuation of mergers and acquisitions has failed to identify if the wealth effects are due to synergies created by corporate combinations or are the result of managerial displacement. Since joint ventures do not entail the same levels of managerial turnover as mergers and acquisitions, joint venture investments provide us with an ideal method of testing the market reaction to synergistic investment. The existence of inter-corporate synergies would ceteris paribus be expected to result in a positive market reaction when new information about joint venture projects is announced. In addition, Burton et al. (1999) argue that stock markets might be expected to react favourably to the announcement of joint venture investments when projects are highly risky, such as the introduction of new technology or marketing a new product. Some projects might be considered too risky for a single company to undertake but such projects may become acceptable to company boards and financial markets if the risks are shared between two or more companies. Studies by McConnell and Nantell (1985), Woolridge and Snow (1990) and Burton et al. (1999) identify small significant positive abnormal returns to announcements of joint ventures, although Chung et al., 1993 find the announcement of international joint ventures to be associated with negative abnormal performance.

The dataset for this study contains a large number of projects which are identified as 
joint venture investments. Some of these are the formation of new joint ventures, others involve new activities or investments by existing joint ventures. In this paper, we test hypotheses regarding the magnitude, direction and determinants of abnormal performance when UK companies announce joint venture activities. We add to the previous literature on the market response to joint venture investments by examining the synergy hypothesis in a UK context as well as including a wider range of different types of projects than previous UK studies (see for example Burton et al., 1999). ${ }^{1}$ Furthermore, we add to our analysis by presenting new evidence on the determinants of the stock market reaction to joint venture investments.

Based on a sample of 158 joint venture investment announcements by listed UK companies, we find at the aggregate level similar abnormal returns to those identified by previous studies (Burton et al., 1999; Woolridge and Snow, 1990). However, more detailed analysis reveals that the market reacts more favourably to the announcement of joint venture investments that are made by smaller companies, are large relative to the size of the company, or are undertaken in the UK or the European Union.

The remainder of the paper is organised as follows. We first provide a brief review of related literature in section 2, before presenting our hypotheses in section 3. A discussion of our data and methodology is contained in section 4. This is followed in section 5 by a cross-sectional analysis of the factors influencing the market response to joint venture investments. Our conclusions are contained in the final section. 


\section{Literature review}

Forming a joint venture is one method of entering new markets, reducing production costs or sharing $R \& D$ costs whilst spreading the risk (and return). There is a limited literature on the subject of wealth effects to the announcement of joint venture formation. The literature is generally split between studies looking at joint ventures in general and those focusing on international joint ventures. McConnell and Nantell (1985) observe positive and significant abnormal returns for their sample of joint venture formations where both or all partners were US firms. Whilst McConnell and Nantell (1985) do not attempt to identify the wealth-creating factors which influence the market reaction to US domestic joint venture formation, they do comment that the similarity between the market reaction to mergers and joint ventures may indicate an inter-corporate synergy effect as the source of the gains to shareholders. The market may perceive that a similar synergy may be more difficult to achieve when the joint venture is undertaken with an international partner.

Studies of the market response to capital investment announcements by Woolridge and Snow (1990) and Burton et al. (1999) contain categories of joint ventures within their studies. Woolridge and Snow (1990) identify a positive and significant abnormal return to the announcement of US joint ventures of $0.8 \%$ on the event day. Burton et al. (1999) examine 82 UK joint ventures, finding a positive and significant abnormal return of $1.59 \%$. Burton et al. (1999) test the cross-sectional correlation between abnormal returns and company size, announcement size, the market-to-book ratio and a prior funding dummy variable, but find no significance. Firm size has, however, been identified as a significant determinant of the magnitude of wealth gains to companies undertaking joint ventures by some US studies (McConnell and 
Nantell, 1985; Keown et al., 1999).

A number of other studies identify factors influencing the success of joint ventures. Koh and Venkatraman (1991) examine joint ventures in the information technology sector and report generally positive market reactions which tend to be greater where the parent companies comes from a related sector. Johnson and Houston (2000) classify joint ventures according to whether they represent horizontal or vertical corporate growth. Rejecting the risk-sharing motivation for undertaking joint ventures, Johnson and Houston (2000) find horizontal joint ventures to provide synergy gains to partners whilst vertical joint ventures are found to provide benefits only to the suppliers.

Mohanram and Nanda (1998) identify strategic considerations, managerial misalignment and complementary resources as the three drivers of the market response to joint ventures investments using a sample of 253 US joint ventures between 1986 and 1993. Pooling of resources is found to positively influence the market reaction, whilst negative reactions are observed for joint ventures which are undertaken by companies with high levels of free cash flow which Mohanram and Nanda (1998) suggest indicates potential for agency costs. Small firms entering into joint ventures with large firms benefited from a signalling effect to achieve positive abnormal returns.

Chung et al. (1993) find that announcements of international joint ventures undertaken by US firms have a negative effect on firm values despite the assumption that projects are being motivated by expectations of greater market share or higher 
profitability. Neither the location of the project nor the specific industry of the project are significant determinants of the negative market responses. Projects involving more than one foreign partner enjoy significant positive abnormal returns. Borde et al. (1998) examine 100 joint ventures involving US companies between 1979 and 1994 and identify that the wealth effects become positive for international joint ventures by US companies into Asia and are less favourable when the project is in a lower risk developing country or is a manufacturing operation. Possible explanations for the negative wealth effect of international joint venture announcements, suggested by Chung et al. (1993), include fears regarding victimisation by hostile partners, diffusion of high-technologies and cultural conflicts between management.

Frohls et al. (2000) examine 320 international joint ventures between 1987 and 1992 involving at least one US partner and one partner from an emerging economy or an industrialised G7 country. ${ }^{2}$ They find that international joint ventures are wealth creating when partners come from an emerging economy but not from a G7 nation. Frohls et al. (2000) also report that a high insider holding for the US partner (5\% to $25 \%)$ leads to a more favourable market response.

\section{Research Hypotheses}

Drawing on the literature on market valuation of joint venture expenditures and the results of previous papers on capital investment projects, we make a number of hypotheses, as detailed below.

Inter-corporate synergies and the risk-sharing effect of a joint venture might be 
expected to result in joint ventures being perceived as being more valuable than single venture projects (McConnell and Nantell, 1985, Burton et al., 1999). Joint ventures can also be a more cost efficient way of entering new markets or developing new products than going it alone. Thus joint ventures may be perceived as being more valuable than single venture projects. We therefore hypothesise:

H1: The market reaction to announcements of capital investment involving a partner will be positive and significant.

Results from previous papers have found company size to be a significant variable in the market valuation of company investment decisions (McConnell and Nantell, 1985, Keown et al., 1999). Market reactions to joint venture announcements might be greater for smaller firms for whom such a project might be considered to add significantly to the company’s stock of investment opportunities. Mohanram and Nanda (1998) identify a signalling effect such that the announcement of joint ventures by small firms may signal a significant value creation potential to the market.

H2: The market reaction to the announcement of joint ventures will be greater for smaller firms.

The market valuation of any commitment of resources would be expected to be related to the size of that commitment of resources relative to the size of the firm (Burton et al., 1999). As the size of the commitment rises, the potential risk and return would also be expected to rise.

H3: The market reaction to the announcement of a joint venture will increase as the size of the project relative to the size of the company increases. 
The hypothesis that the market reaction to the announcement of a joint venture is positively related to the company's commitment to the project is tested. This is a related hypothesis to the hypothesis that the relative size of the project will be an important determinant of the market valuation of the project (Burton et al., 1999).

H4: The market reaction to the announcement of a joint venture will increase as the company's share of the joint venture increases.

Finally, the increased level of risk attached to international projects might be expected to reduce the level of abnormal return. Previous studies, which have examined how markets react to international joint ventures, have identified that investments outside the country of origin are found to exhibit negative abnormal returns in some studies whilst the empirical evidence suggests that the market values domestic joint ventures highly (Chung et al., 1993, Borde et al., 1998 and Frohls et al., 2000). In this study, the significance of the location of joint venture investments by UK companies is tested. The hypothesis tested here is that investments by UK companies in UK-based joint ventures will be valued more highly than overseas investments since overseas projects might be considered risky by financial markets. Thus we hypothesise that:

H5: The market reaction to announcements of joint ventures will be greater for domestic projects than for international projects.

\section{Data and Methodology}

The initial dataset was made up of 229 capital investment announcements from the Extel News cards for the five-year period from September 1991 to September $1996 .^{3}$ 
The Financial Times Extel database records all official announcements of company news released through the Stock Exchange Regulatory News Service. Stock and market-index (the FT All-Share index ${ }^{4}$ ) returns data were obtained from Datastream. Projects were classified as a joint venture activity if they involved either the formation of a joint venture or were new projects undertaken by an existing joint venture. $^{5}$

It is a characteristic of capital investment announcements that such information is often released at the same time as other announcements. In order to preserve the integrity of the dataset, announcements were excluded from the dataset in cases where other announcements were made within one day of the joint venture announcement. There were 69 cases of contemporaneous news announcements and once two large positive outliers were also excluded from the empirical results, the final dataset comprised of 158 announcements.

We report abnormal returns calculated using the market-adjusted returns method, although our results are robust to various model specifications. ${ }^{6}$ The mean abnormal return on the day of the joint venture announcements amounts to $0.5 \%$ and is significant at the $1 \%$ level using both a t-test and a Wilcoxon test. ${ }^{7}$ There is therefore strong support for hypothesis 1 . Research and development projects exhibit the highest level of abnormal returns (1.1\%) followed by product/market diversification (0.5\%) and capital expenditures (0.2\%). Only $R \& D$ joint ventures produced a significant t-test at the $5 \%$ significance level. These findings suggest that firms experience significant positive returns as a result of inter-corporate synergies. 
Insert table 1 about here

\section{Factors Influencing the Market Response to Joint Venture Investments}

This section contains cross-sectional regressions of abnormal returns against a set of independent variables selected from the literature which might be expected to influence the magnitude and sign of abnormal returns. The relationship we examine is based on the hypotheses developed earlier in this paper. For each variable, we use either a dummy variable or a continuous variable. Dummy variables are used for the location categories (UK for United Kingdom and Ireland, EU for projects outside the UK and Ireland but in the European Union or western Europe, OE for projects in non-European Union European countries, AS for projects in Asia or Australasia and NA for projects in the United States or Canada). The location categories represent the location of the project which was identified from the text of the project announcements. Continuous variables are used for firm size (LOGS), relative project size (PS) and the proportion of the joint venture attributable to the company (SH). Firm size data was collected from Datastream and entered into the analysis after a log transformation. The relative project size (PS) was calculated as the size of the project divided by the market capitalisation of the company. ${ }^{8}$ The size of the project was taken to be the figure announced (wherever given). The value for the proportion of the joint venture attributable to the company was collected from the announcements on Extel.

We apply the following regression model (1): 
$\varepsilon_{\mathrm{i}}=\alpha+\beta_{1} \mathrm{LOGS}+\beta_{2} \mathrm{PS}+\beta_{3} \mathrm{SH}+\beta_{4} \mathrm{UK}+\beta_{5} \mathrm{EU}+\beta_{6} \mathrm{OE}+\beta_{7} \mathrm{AS}+\beta_{8} \mathrm{NA}+\mathrm{e}$

where:
$\varepsilon_{\mathrm{i}}=$ abnormal returns on share $\mathrm{i}$
$\alpha \quad=$ intercept
$\beta_{1}, \beta_{2}$, etc. $\quad=$ regression coefficients.
e $=$ error term
LOGS = log of market capitalisation
PS $\quad$ = project size (relative to the market capitalisation)
$\mathrm{SH}=$ proportion of the joint venture attributable to the company
EU, OE, AS, NA = dummy variables representing location categories, where EU refers to European Union projects, OE to other European projects, AS to projects in Asia and Australia and NA to projects in North America.

The correlations between the independent and dependent variable were examined to test for violation of OLS assumptions and to test for correlation with market-adjusted returns. Although some of the dummy variables are correlated, there is no problem of multicollinearity between the continuous variables, so no exclusions were necessary ${ }^{9}$.

It is not necessary or practical to include all possible combinations of dependent and independent variables in the reported findings of this paper. In table 2 we report the main regression results from application of equation (1). The models reported were 
selected on the basis of the correlation with abnormal returns and evidence of collinearity.

\section{Insert table 2 about here}

Company size is negatively related to the level of abnormal returns, thus providing support for hypothesis 2. Although the value of the coefficient is fairly small, the coefficient is significant at the $1 \%$ level for the sample as a whole. Since we use daily data, the size effect detected here can be attributed to the announcement of company investment projects rather than to a general stock market size effect (Dimson and Marsh, 1986). The negative coefficient for company size supports the findings of McConnell and Nantell (1985) and Keown et al. (1999) for the US market, although Burton et al. (1999) find no significant correlation between abnormal returns and company size for UK joint ventures. The negative size effect indicate that any joint venture undertaken by a small firm would be of considerably greater significance than for a large firm. This finding is not surprising since a joint venture for small firms may represent a significant breakthrough in terms of creating new growth opportunities whereas for large firms such a project may only change the costs or risks associated with existing growth opportunities.

The relative project size variable is included in models 2 and 8 . There were 69 cases of project size being included as part of the announcement of a joint venture investment, of which 48 were categorised as capital expenditure projects. In model 2 where all 69 observations were included, the regression coefficient is positive (0.118) and significant at the 1\% level. Our findings contradict those of Burton et 
al. (1999), who find no significant relationship between relative announcement size and abnormal returns. However, in model 8, which includes only the 48 observations of project size in the category of capital expenditure projects, the regression coefficient is still positive, but only significant at the $10 \%$ level. The evidence presented here indicates that the market reaction to joint venture investments increases as the relative size of the project increases, as predicted in hypothesis 3 .

The proportion of the funding of the joint venture attributable to the company is included in model 3. The number of observations is considerably reduced, but the regression coefficient for $\mathrm{SH}$ is significant at the $1 \%$ level. The adjustment to abnormal returns is small and negative (-0.1\%). Models were also examined where the SH variable was included as a dummy which took the value of 1 when the company's stake in the project is greater than $50 \%$. The coefficient for the $\mathrm{SH}$ dummy was insignificant in all cases. There is no evidence here which could allow the acceptance of hypothesis 4 which stated that the market reaction to the announcement of a joint venture will increase as the company's share of the joint venture increases.

The dummy variables representing the location of projects are significant in various models depending on the model specification. Models 4, 5 and 7 include the EU projects dummy variable as an explanatory variable and suggest a significant, positive adjustment to abnormal returns of between $2.1 \%$ and $6 \%$ depending on the category of joint venture investments used as the dependent variable. In models 3 and 9, the regression coefficient for the dummy variable representing Asian and Australian projects is significant at the 5\% level and $10 \%$ level respectively 
indicating a downward adjustment of approximately 1\%. The dummy variable for projects from European countries outside the European Union was found to be significant in model 3 which was based on a limited subset of the data containing information about the proportion of the ownership of the project attributable to the announcing company. The difference between Asian and Australian projects and the rest of the sample was tested using an independent samples t-test and a nonparametric Mann-Whitney test which were both significant at the $5 \%$ level. This evidence indicates that the market values European-based projects more highly than joint ventures which are based further a field.

The mean market-adjusted return is $0.9 \%$ for 82 cases of projects located in the UK and Ireland whilst the return is on average only $0.2 \%$ for projects located outside the UK and Ireland. An independent samples t-test of the difference between the mean market-adjusted returns for the two categories indicated that the market-adjusted return for UK or Ireland based projects is significantly greater at the $10 \%$ level than the market-adjusted return for non-UK and Ireland based projects. ${ }^{10}$ There is therefore support for hypothesis 5.

Chung et al. (1993), Borde at al. (1998) and Frohls et al. (2000) identify different levels of abnormal performance for international joint ventures depending on the location of the project. Chung et al. (1993) find negative abnormal performance to international joint ventures by US firms. However, contradictory evidence is provided by Borde et al. (1998), who identify positive abnormal returns when international joint ventures by US firms were undertaken in Asia, and by Frohls et al. (2000) who find positive abnormal returns when joint ventures by US firms were 
undertaken in Eastern Europe or China. For our sample, we find that for all projects except those in Asia and Australia (AS), the abnormal return is positive on average, although small for projects in North America. The overall difference between the abnormal returns for location categories was tested using a one-way ANOVA and a non-parametric Kruskal-Wallis test. The one-way ANOVA was significant at the $1 \%$ level indicating that the location categories are an important determinant of how markets will react to joint venture announcements. However, the Kruskal-Wallis test was only significant at the $10 \%$ level.

\section{Conclusions}

This paper has examined the stock market valuation of announcements of joint venture investments. The dataset contained 158 announcements involving one or more partners. These projects may be undertaken as a method of reducing the risk to the company or in order to gain access to markets which might otherwise be beyond the resources of the company. Announcements were included in the joint venture category if they were a joint venture formation or an investment by an existing joint venture. However, joint venture formations were difficult to separate from investments by existing joint ventures so only results for the set as a whole were reported.

Whilst several abnormal return generating models were compared, no significant difference was detected. The market-adjusted return method was reported and used in the cross-sectional regressions. The overall finding is that the abnormal return on the day of the announcement of joint venture investments is significant and positive, with a mean of $0.5 \%$. This evidence supports the hypothesis expressed by 
McConnell and Nantell (1985) that wealth gains from corporate combinations are the result of an inter-corporate synergy effect.

Our analysis also reveals new evidence about the factors which influence the wealth effects of joint ventures by UK companies. The cross-sectional regressions revealed a negative and significant relationship between market capitalisation and marketadjusted returns. Project size also appears to be highly significant in the valuation of joint venture investments. Contrary to the findings of Burton et al. (1999), relative project size exhibited high levels of cross-sectional significance with marketadjusted returns. However, a negative and significant relationship between a dummy variable representing projects in Asia and market-adjusted returns was also detected which implies that markets are cautious about financing projects in that region.

Finally, a positive and significant correlation between domestic projects and marketadjusted returns was also identified. An independent samples t-test confirmed that the market valuation of domestic joint ventures was significantly higher than international joint ventures. However, this finding may be the result of a lack of new information contained within the announcement of international joint ventures.

The authors would like to express thanks to Ian Hirst and Seth Armitage for comments on earlier drafts of this paper. 


\section{Bibliography}

Borde, S.F., Whyte, A.M., Wiant, K.J., and Hoffman, L.J., (1998). 'New Evidence on Factors that Influence the Wealth Effects of International Joint Venture Announcements', Journal Of Multinational Financial Management, 8 (1), 6175.

Brown, S.J. and Warner, J.L., (1985) ‘Using Daily Stock Returns: The Case of Event Studies', Journal of Financial Economics, 14, 3-31.

Burton, M.B., Lonie, A.A., and Power, D.M., (1999) 'The Stock Market Reaction to Investment Announcements: The Case of Individual Capital Expenditure Projects’, Journal of Business Finance and Accounting, 26 (5\&6), 681-708.

Chung, I.L., Koford, K.J. and Lee, I., (1993). 'Stock Market Views of Corporate Multinationalism: Some Evidence from Announcements of International Joint Ventures’, The Quarterly Review of Economics and Finance, 33, 5, 275-293.

Dimson, E. and Marsh, P., (1986). 'Event Study Methodology and the Size Effect: The Case of UK Press Recommendations', Journal of Financial Economics, $17,113-142$.

Frohls, M.A., Keown, A.J., McNabb, M.M., and Martin, J.D., (2000). 'Growth Opportunities, Corporate Governance and the Market Value of Multinational Joint Ventures’, Working Paper Series, www.ssrn.com.

Johnson, S.A., and Houston, M.B., (2000). 'A Re-Examination of the Motives and Gains in Joint Ventures', Journal of Financial and Quantitative Analysis, March, 67-86.

Keown, A. J., Laux, P.A., and Martin, J.D., (1999). 'The Information Content of Corporate Investment Announcements: The Case of Joint Ventures', Working Paper Series, www.ssrn.com. 
Koh, J. and Venkatraman, N., (1991). 'Joint Venture Formations and Stock Market Reactions: An Assessment in the Information Technology Sector', Academy of Management Journal, 34, 869-92.

McConnell, J. and Nantell, T., (1985). 'Corporate Combinations and Common Stock Returns’, Journal of Finance, 15, 519-536.

Mohanram, P., and Nanda, A., (1998). 'When do Joint Ventures Create Value?', WwW.ssrn.com.

Strong, N., (1992) 'Modelling Abnormal Returns: A Review Article', Journal of Business Finance and Accounting, 19, 533-553.

Woolridge, J.R. and Snow, C., (1990). 'Stock market reaction to strategic investment decisions’, Strategic Management Journal, 11, 5, September, 353-363. 
Table 1

Market-adjusted abnormal returns joint venture project announcements.

\begin{tabular}{ccccccc}
\hline & N & Mean & Std. & Median & Min. & Max. \\
& \multicolumn{7}{c}{ Deviation } \\
\hline All JV & 158 & $0.005^{* * *}$ & 0.023 & $0.002^{* * *}$ & -0.099 & 0.120 \\
& & & & & & \\
RD & 44 & $0.011^{* *}$ & 0.028 & $0.004^{* * *}$ & -0.034 & 0.120 \\
PM & 47 & 0.005 & 0.025 & $-0.001^{* * *}$ & -0.071 & 0.093 \\
CE & 67 & 0.002 & 0.018 & $0.003^{* * *}$ & -0.099 & 0.039 \\
\hline
\end{tabular}

The table contains market-adjusted abnormal returns on the day of joint venture project announcements for the sample of 158 joint ventures by listed UK companies. The sample is further subdivided into 3 mutually exclusive categories of $\mathrm{RD}=$ research and development projects, $\mathrm{PM}=$ product/market diversification projects, and $\mathrm{CE}=$ capital expenditure projects. ***indicates a significant t-test of the mean or a significant Wilcoxon test of the median at the $1 \%$ level, ** indicates a significant t-test of the mean or a significant Wilcoxon test of the median at the $5 \%$ level. 
Table 2

Regression Analysis of Joint Venture Abnormal Returns

\begin{tabular}{|c|c|c|c|c|c|c|c|c|c|c|c|}
\hline Model & $\begin{array}{l}\text { Dependent } \\
\text { Variable }\end{array}$ & Sample & Const. & LOGS & PS & $\mathrm{SH}$ & $E U$ & $\mathrm{OE}$ & AS & Adj. $\mathrm{R}^{2}$ & $\bar{F}$ \\
\hline 1 & All JV & 156 & $\begin{array}{c}0.021 \\
(0.000)\end{array}$ & $\begin{array}{l}-0.002 \\
(0.005)\end{array}$ & & & & & & 0.044 & $\begin{array}{c}8.129 \\
(0.005)\end{array}$ \\
\hline 2 & All JV & 69 & $\begin{array}{c}-0.002 \\
(0.565)\end{array}$ & & $\begin{array}{c}0.118 \\
(0.003)\end{array}$ & & & & & 0.108 & $\begin{array}{c}9.394 \\
(0.003)\end{array}$ \\
\hline 3 & All JV & 30 & $\begin{array}{c}0.027 \\
(0.019)\end{array}$ & & & $\begin{array}{l}-0.001 \\
(0.006)\end{array}$ & & $\begin{array}{c}0.033 \\
(0.033)\end{array}$ & & 0.262 & $\begin{array}{c}6.324 \\
(0.005)\end{array}$ \\
\hline 4 & All JV & 156 & $\begin{array}{c}0.022 \\
(0.000)\end{array}$ & $\begin{array}{l}-0.002 \\
(0.008)\end{array}$ & & & $\begin{array}{c}0.021 \\
(0.016)\end{array}$ & & $\begin{array}{c}-0.010 \\
(0.012)\end{array}$ & 0.115 & $\begin{array}{c}7.776 \\
(0.000)\end{array}$ \\
\hline 5 & $\mathrm{RD}$ & 43 & $\begin{array}{c}0.010 \\
(0.024)\end{array}$ & & & & $\begin{array}{c}0.060 \\
(0.035)\end{array}$ & & & 0.081 & $\begin{array}{c}4.767 \\
(0.035)\end{array}$ \\
\hline 6 & $\mathrm{PM}$ & 46 & $\begin{array}{c}0.115 \\
(0.038)\end{array}$ & $\begin{array}{l}-0.014 \\
(0.037)\end{array}$ & & & & & & 0.630 & $\begin{array}{c}9.510 \\
(0.037)\end{array}$ \\
\hline 7 & PM & 46 & $\begin{array}{c}0.003 \\
(0.324)\end{array}$ & & & & $\begin{array}{c}0.040 \\
(0.022)\end{array}$ & & & 0.092 & $\begin{array}{c}5.662 \\
(0.022)\end{array}$ \\
\hline 8 & CE & 48 & $\begin{array}{c}-0.001 \\
(0.701)\end{array}$ & & $\begin{array}{c}0.077 \\
(0.092)\end{array}$ & & & & & 0.039 & $\begin{array}{c}2.952 \\
(0.092)\end{array}$ \\
\hline 9 & CE & 66 & $\begin{array}{c}0.005 \\
(0.085)\end{array}$ & & & & & & $\begin{array}{l}-0.007 \\
(0.097)\end{array}$ & 0.027 & $\begin{array}{c}2.834 \\
(0.097)\end{array}$ \\
\hline
\end{tabular}

The table represents the results from regression of event day market-adjusted returns (All JV = all joint venture announcements, RD = research and development announcements, $\mathrm{PM}=$ product/market diversification announcements, $\mathrm{CE}=$ capital expenditure announcements) on a set of independent variables., Const = the constant term. The independent variables are LOGS = Company Size, PS = Project Size, SH = the proportion of the joint venture attributable to the company, EU = Projects in the European Union, OE = Projects in Europe but outside the European Union, AS = Projects in Asia. The significance of the t-test of each variable is given underneath in parentheses. 


\section{Endnotes}

${ }^{1}$ Burton et al. (1999) restricted their analysis to a sample of asset purchases for which the value of the transaction was disclosed. We also analyse asset purchases (which are categorised as capital expenditures in our sample), but extend the analysis to also include research and development announcements and product/market diversification projects by joint ventures. The size of the project was announced in 69 of the 158 cases of joint venture activity in our sample.

${ }^{2}$ Emerging economies were classified as former communist countries in Eastern Europe and China.

3 The dataset was identified from various categories in the Extel database. Each announcement in the Extel categories of activities, assets, commercial operations, diversification, exploration findings, joint ventures and operations were carefully checked for information regarding joint venture activity. Each announcement normally offers at least a paragraph of information.

${ }^{4}$ The use of alternative market indices was examined, but had a minimal impact since abnormal returns were calculated on a daily basis (Strong 1992; Brown and Warner 1985).

${ }^{5}$ Whilst it was simple to identify if a project was undertaken as a joint venture, in many cases it was not clear whether it was a new joint venture or a partnership which was already established. For this reason the sample was not split between joint venture formations and investments by existing joint ventures.

${ }^{6}$ The results of the market adjusted returns method (assuming $\beta$ of 1 and a $\alpha$ of zero for all companies) were compared with the results of several other models including the market model using a beta calculated by making trade-to-trade adjustments. This method was not reported due to the large amount of data which is lost due to the limited 
observations available to estimate alphas and betas. There was no significant difference between the results of the various models except in cases where alphas and betas were estimated from very few observations. Abnormal returns and significance tests calculated using the market model, a trade-to-trade adjusted market model and a tradeto-trade adjusted index model are available from the authors upon request.

${ }^{7}$ Analysis was also undertaken for a longer event window, from 3 days prior, to 3 days after, the day of the project announcement. No significant abnormal returns were observed for any day other than the day of the joint venture announcement.

${ }^{8}$ Project size is calculated using only each partner's commitment and not the size of the whole project.

9 The correlation matrix is available from the authors upon request.

10 This significance was not repeated using a Mann-Whitney U independent samples test. 